\title{
Evaluating the importance of surface soil contributions to reservoir sediment in alpine environments: a combined modelling and fingerprinting approach in the Posets-Maladeta Natural Park
}

\author{
L. Palazón ${ }^{1}$, L. Gaspar ${ }^{2}$, B. Latorre ${ }^{1}$, W. H. Blake ${ }^{2}$, and A. Navas ${ }^{1}$ \\ ${ }^{1}$ Department of Soil and Water, Estación Experimental de Aula Dei (EEAD-CSIC), Avda. Montañana 1005, \\ Zaragoza, 50059, Spain \\ ${ }^{2}$ School of Geography, Earth and Environmental Sciences, Plymouth University, Plymouth, Devon, PL4 8AA, UK \\ Correspondence to: L. Palazón (lpalazon@eead.csic.es)
}

Received: 1 April 2014 - Published in Solid Earth Discuss.: 7 May 2014

Revised: 15 July 2014 - Accepted: 16 July 2014 - Published: 8 September 2014

\begin{abstract}
Soil in alpine environments plays a key role in the development of ecosystem services and in order to maintain and preserve this important resource, information is required on processes that lead to soil erosion. Similar to other mountain alpine environments, the Benasque catchment is characterised by temperatures below freezing that can last from November to April, intense rainfall events, typically in spring and autumn, and rugged topography which makes assessment of erosion challenging. Indirect approaches to soil erosion assessment, such as combined model approaches, offer an opportunity to evaluate soil erosion in such areas. In this study (i) the SWAT (Soil and Water Assessment Tool) hydrological and erosion model and (ii) sediment fingerprinting procedures were used in parallel to assess the viability of a combined modelling and tracing approach to evaluate soil erosion processes in the area of the Posets-Maladeta Natural Park (central Spanish Pyrenees). Soil erosion rates and sediment contribution of potential sediment sources defined by soil type (Kastanozems/Phaeozems; Fluvisols and Cambisols) were assessed. The SWAT model suggested that, with the highest specific sediment yields, Cambisols are the main source of sediment in the Benasque catchment and Phaeozems and Fluvisols were identified as the lowest sediment contributors. Spring and winter model runs gave the highest and lowest specific sediment yield, respectively. In contrast, sediment fingerprinting analysis identified Fluvisols, which dominate the riparian zone, as the main sediment source at the time of sampling. This indicates the importance of connectivity as well as potential differences in the
\end{abstract}

source dynamic of material in storage versus that transported efficiently from the system at times of high flow. The combined approach enabled us to better understand soil erosion processes in the Benasque alpine catchment, wherein SWAT identified areas of potential high sediment yield in large flood events but sediment fingerprinting identified areas that, due to high connectivity, contribute more to channel-stored sediment deposits.

\section{Introduction}

Alpine soil performs important ecological functions related to (i) the quality and quantity of water resources, (ii) storage of carbon, (iii) flood risk alleviation, (iv) maintenance and character of biodiversity and (v) the value of landscapes as habitats. Mountain soils suffer from intrinsic vulnerability to natural stresses such as extreme rainfall (Giannecchini et al., 2007; Meusburger and Alewell, 2008) and changes in precipitation (Stanchi et al., 2013) and human activities can exacerbate this. Soils are a natural resource and their protection is vital for the proper and sustainable functioning of alpine environments.

Mountain systems all over the world are unique in their ecology and diversity (Alewell et al., 2008). However, extreme topography and intense climate, as seen in the Benasque alpine catchment (Spain), the focus of this study, result in high instability, fragility and sensitivity for these ecosystems (Gellrich and Zimmermann, 2007). 
Simultaneously, human society has exploited most mountain environments to a maximum (Lasanta et al., 2006) which have experienced severe degradation since the Middle Ages (Höchtl et al., 2005; Valero-Garcés et al., 2006). Economic, societal and environmental changes are often an immediate threat to mountain systems and careful, evidence-based planning is needed (Alewell et al., 2008). Thus, methods to describe and predict ecosystem stability and threats in mountain systems are urgently needed (Garcia-Ruiz et al., 1996). One inherent parameter of ecological stability is the status of soils. In mountain ecosystems, soil health and stability underpins slope stability, water budgets (drinking water reservoirs as well as flood prevention), vegetation productivity, ecosystem biodiversity and nutrient production.

Although alpine soils generally have high density vegetation covers, they are vulnerable to soil erosion because of steep slopes and intense climatic events. Vegetation cover is an important parameter with respect to soil erosion in mountain environments because it protects soil by reducing water runoff and dampening the kinetic energy of rain drops, by increasing water infiltration into the soil matrix and by sheltering and stabilising the terrain around the roots (Schindler Wildhaber et al., 2012). Changes of land use can modify the water balance in certain mountain areas with negative impacts on the lowlands, which support higher density populations. Depending on region and altitude, projections of further climatic warming will shorten the duration of snow cover by up to 100 days, with earlier snowmelt in spring (Beniston, 2006; Horton et al., 2006; Jasper et al., 2004). In Europe, a rising snowline, intensified precipitation during the winter and strong leaching effects with no or sparse vegetation cover in late fall and early spring will result in an increase of erosion (Fuhrer et al., 2006). Increased erosion is also likely in the alpine environment under stronger climates for example where (i) periods of drought are followed by rain events of increased intensity (Brunetti et al., 2006; Schmidli and Frei, 2005) or (ii) rapid snowmelt in late spring is overlapped with intense rain events, producing large catastrophic floods, as observed on 18 January 2013 in the Benasque catchment.

The spatial and temporal dynamics of sediment production and inputs to the hydrological network in alpine environments are conditioned by the characteristics of high mountain climate, especially with the presence of the snow cover periods and its related snowmelt. During the winter one of the processes affecting soil aggregate stability is freezing and thawing cycles, providing small soil aggregates which can be easily exported by the early spring snowmelt. This has a great influence on soil erodibility in the spring. In addition, these regions are mostly characterised by rugged topography and large precipitation that favour quick and substantial runoff.

The combined effects of continuing global climate change and future land use change might significantly increase soil degradation (Beniston, 2006; Fuhrer et al., 2006). Suitable methods to describe and predict soil degradation in mountain areas with low accessibility, steep topography and extreme climate are urgently needed for suitable planning processes in alpine regions (Alewell et al. 2008). Indirect approaches to soil erosion assessment, e.g. models and tracers, offer opportunity to overcome the logistical challenges of working in inaccessible mountainous regions.

The Soil and Water Assessment Tool (SWAT) (Arnold et al., 1998) is a hydro-sedimentary model that was developed to predict the effects of different management practices on water quality, sediment yield and pollution-loading in catchments. SWAT has been widely implemented to perform hydrological simulations to estimate streamflow timing and volumes from mountainous catchments worldwide (e.g. Gikas et al., 2006; Zhang et al., 2008; Yu et al., 2011; Rahman et al., 2013). However, there have been few studies that evaluate sediment production in alpine mountain catchments (Abbaspour et al., 2007; Rostamian et al., 2008; Flynn and Van Liew, 2011; Palazón and Navas, 2013).

Viewed in simple terms, sediment source fingerprinting applied to catchment systems aims to provide information on the source of the sediment transported by a river (Walling, 2013). The fingerprinting procedure employs statistical testing of a range of source material tracer properties to select a subset that discriminate sources (Collins and Walling, 2002). Sediment fingerprinting approaches offer the potential to quantify the contribution of different sediment sources, evaluate catchment erosion dynamics and support the development of management plans to tackle the reservoir siltation problems. In the last 30 years, sediment source fingerprinting investigations have expanded greatly in response to a growing need for information on sediment source and to technological advances which facilitate such work (Walling, 2013). However, source fingerprinting techniques continue to be most widely applied in agricultural and forest catchments (e.g. Owens et al., 2000; Collins et al., 2010; MartínezCarreras et al., 2010b; Blake et al., 2012; Schuller et al. 2013) and the opportunity in alpine catchments remains unexploited.

The Benasque alpine catchment in Posets-Maladeta Natural Park, located in the central Spanish Pyrenees, is surrounded by the highest peaks ( $>3000 \mathrm{~m}$ a.s.l.) of the Pyrenean range. Alatorre et al. (2010) studied soil erosion and sediment delivery using the WATEM/SEDEM model for the Barasona catchment that includes the Benasque catchment. Soil loss due to water erosion represents an increasing threat with climate change which has been predicted to affect precipitation regimes, frequency of extreme meteorological events, snowmelt and vegetation (IPCC, 2007). This study represents a preliminary investigation to develop knowledge of soil erosion processes in the Benasque alpine catchment. The aim is to assess the viability of a combined modelling and tracing approach for evaluating soil erosion processes in alpine soils and dominant sources of sediments. Working within a reservoir catchment, specific objectives are (1) to undertake spatial and temporal modelling with SWAT 
to identify soils which generate sediment and (2) to use composite fingerprinting properties to identify the principal sources of sediment delivered to the reservoirs.

\section{Study area}

The Benasque catchment is located within the PosetsMaladeta Natural Park (central Spanish Pyrenees). The Natural Park, created in 1994, is an autonomous legislative body engaged in the conservation of natural species and values. The park is included in the European Natura 2000 network. The park has a biological diversity typical of high mountain bioclimatic zones with endemic or endangered species. The natural landscape is also of conservation value with a glacially formed valley, moraines and glacial lakes, and a karstic landscape in its headwater. The remnant AnetoMaladeta glacial system is located in the northernmost part of the catchment and is under the Spanish protection directive of the Natural Monuments of the Pyrenean glaciers.

The catchment is situated in the Axial Pyrenees Structural Unit composed of Paleozoic rocks (quartzite, limestone, and slate) and granodiorite with a very complex tectonic organisation. The mean elevation of the catchment is $2213 \mathrm{~m}$ a.s.l (metres above sea level) and ranges from $1039 \mathrm{~m}$ a.s.l. at the outlet to $3404 \mathrm{~m}$ a.s.l. (Aneto Peak). The climate is defined as mountain type, wet and cold, with both Atlantic and Mediterranean influences (García-Ruiz et al., 1985). The village of Benasque, at $1138 \mathrm{~m}$ a.s.l., receives an average annual precipitation of $1182 \mathrm{~mm}$ which further increases to more than $2500 \mathrm{~mm}$ on the highest divides (García-Ruiz et al., 2001). Above $1000 \mathrm{~m}$ a.s.l., the average annual temperature is lower than $10^{\circ} \mathrm{C}$ and at $2000 \mathrm{~m}$ the mean temperature is around $5^{\circ} \mathrm{C}$ (Puigdefábregas and Creus, 1973). Thus, between November and April, the $0{ }^{\circ} \mathrm{C}$ isotherm is around 1600-1700 m a.s.l. (García-Ruiz et al., 2001), meaning more than $85 \%$ of the catchment is above this isotherm (Fig. 1). The hydrologic regime of the area is transitional nivo-pluvial with clear nival trends tempered by pluvial influences (López-Moreno et al., 2002). The study catchment includes two reservoirs, Linsoles and Paso Nuevo (Fig. 1), both with a storage capacity of $3 \mathrm{hm}^{3}$, regulate 118 and $283 \mathrm{~km}^{2}$ of the Ésera headwater, respectively, with an impounded runoff index (IR) of 0.016 and 0.022 each. Based on their IR index and using the equation developed by Heinemann (1981) for small reservoirs, Linsoles and Paso Nuevo have a 45 and $60 \%$ sediment trap efficiency, respectively. This suggests that hillslope-derived sediment loads transported through the reservoirs and the fluvial network are effectively exported out of the catchment. The river channel has clean blocky alluvial deposits and rocky embedded channels.

A well-developed karst system is located in the northern area of the catchment (Fig. 1) and the discharge of the upper part of the Ésera River flows underground through the
Table 1. Distribution of land covers, soil types and slope ranges (\%) in SWAT input data of the Benasque catchment (BC) and of subcatchments (PNS: Paso Nuevo; and LS: Linsoles subcatchments).

\begin{tabular}{lllll}
\hline & Type & Area $(\%)$ & & \\
& & BC & PNS & LS \\
\hline Land covers & Urban & 0.1 & 0.0 & 0.2 \\
& Alluvial deposits & 0.3 & 0.0 & 0.4 \\
& Pine forests & 17.7 & 17.4 & 17.9 \\
& Mixed forests & 2.6 & 1.3 & 3.3 \\
& Deciduous forests & 5.3 & 1.2 & 7.5 \\
& Evergreen forests & 6.9 & 12.3 & 4.0 \\
& Scrublands & 2.4 & 0.8 & 3.3 \\
& Disperse scrublands & 16.5 & 19.0 & 15.2 \\
& Pastures & 16.3 & 10.2 & 19.6 \\
& Range grasses & 3.8 & 0.8 & 5.5 \\
& Rock outcrops & 27.6 & 36.4 & 22.9 \\
& Water & 0.4 & 0.6 & 0.2 \\
\hline Soil types & Cambisols & 22.7 & 28.1 & 19.8 \\
& Fluvisols & 0.7 & 0.2 & 1.0 \\
& Kastanozems & 29.5 & 21.7 & 33.7 \\
& Leptosols & 13.7 & 13.6 & 13.8 \\
& Phaeozems & 5.7 & 0.0 & 8.8 \\
& Rock outcrop & 27.6 & 36.4 & 22.9 \\
\hline Slope ranges & 0-20 & 7.9 & 5.8 & 9.0 \\
& 20-40 & 20.9 & 17.3 & 22.7 \\
& 40-60 & 27.9 & 27.4 & 28.2 \\
& 60-75 & 17.4 & 18.2 & 17.0 \\
& 75-9999 & 25.9 & 31.2 & 23.1 \\
\hline & & & & \\
& & & & \\
& & &
\end{tabular}

Jueu karst system to the upper Garonne River (Aran Valley, Spain).

Rock outcrops cover more than $25 \%$ of the catchment (Table 1). The cultivated areas, comprising range grasses and vegetable gardens, cover a small area $(3 \%)$ and are limited to the valley floors. The pine forest of Pinus sylvestris is at its greatest extent between 1200 and $1700 \mathrm{~m}$ a.s.l., alternating with Abies alba and small formations of Fagus sylvatica in shady places. However, above $1700 \mathrm{~m}$ many forests have been removed to facilitate the extension of pasture (GarcíaRuiz and Del Barrio, 1990). Above $2500 \mathrm{~m}$ bare rocks with sparse plants increasingly dominate the landscape. The soils of the catchment are stony, shallow and alkaline, overlying fractured bedrock with textures from loam to sandy loam. Because the Benasque catchment was deglaciated at the beginning of the Holocene, the soils of the catchment are young and strongly influenced by a periglacial environment. On steep slopes, where Leptosols (with rendzic Leptosols) and lithic Kastanozems are developed, soils are shallow and regularly truncated. More developed soils, such as Cambisols and Phaeozems are found in the lower areas of the catchment, and Fluvisols cover the valley floors (Fig. 2 and Table 1). 



Legend

- Mountain peaks

- Benasque Village

- Channel bed sediments

- Soil samples

- Reservoirs

$\square$ Precipitation gage

- Temperature gage

Glacial system

Karst system catchment Hydrological network Benasque catchment

\section{\begin{tabular}{llllll}
0 & 1.5 & 3 & 6 & 9 & 12 \\
\hline & & &
\end{tabular}}

Figure 1. Location of the Benasque catchment (a). Map of the $0{ }^{\circ} \mathrm{C}$ isotherm (b). Distribution of soil and sediment samples, climate stations, the Paso Nuevo and Linsoles reservoirs (c). 



Figure 2. Distribution of soil types, land covers and slope ranges in the Benasque catchment.

\section{Material and methods}

\subsection{The SWAT model}

SWAT, the Soil and Water Assessment Tool, is a physically based, semi-distributed, agro-hydrological model that operates on a daily time step (as a minimum) at catchment scale (Arnold et al., 1998). The model is capable of continuous hydrological simulation in large complex catchments with varying weather, soils and management conditions. Major model components include weather, hydrology, soil temperature and properties, plant growth, nutrients, 
pesticides, bacteria and pathogens, and land management. Theory and details of different processes integrated in the SWAT model are available online in SWAT documentation (http://swatmodel.tamu.edu/).

SWAT can analyse catchments by discretising into subbasins, which are then further subdivided into hydrological response units (HRUs). The sediment from sheet erosion for each HRU is calculated using the Modified Universal Soil Loss Equation (MUSLE; Williams and Berndt, 1977). Erosion and sediment delivery are estimated as a function of a runoff energy factor as well as physical factors such as soil erodibility, slope steepness and cover, which correspond to flow volume within the channel on a given day. Water redistribution in the HRUs is affected by soil temperature. If temperature in a particular soil layer is $\leq 0^{\circ} \mathrm{C}$, no redistribution is allowed from that layer. Moreover, the erosive power of rainfall and runoff will be less when snow cover is present than when there is no snow cover. The computed loads are then routed through the channel network based on a simplified version of the method of Bagnold (1977), where sediment deposition or erosion is determined based on the unique sediment transport capacity of the individual routing reach and by the upstream continuum of sediment from other subcatchment and channel reaches (Neitsch et al., 2010).

\subsubsection{SWAT inputs}

The HRUs are defined by distinctive combinations of categorised land covers, soil types, and slope. Compiling the input data needed to run the model required considerable research (as detailed by Palazón and Navas, 2014), as well as documenting and adapting the available information, since there were few or no tabulated data to characterise the catchment.

Topographic information was based on a digital elevation model (DEM) obtained from the Spanish National Geographic Institute (IGN, 2011) with a $25 \mathrm{~m}$ grid cell spatial resolution. Given the large slope variations in the catchment, five categories of slope $(0-20 \%, 20-40 \%, 40-60 \%$, $60-75 \%$ and $>75 \%$ ) were defined and derived to the DEM to characterise the variety of the different surfaces (Fig. 2).

The Digital Soil Map of Aragón at a scale of 1:500000 (Soil Map of Aragón, Machín, unpublished data, 2000) was used to define five soil types across the Linsoles catchment (Fig. 2). A user soil database was developed with the required information on the soil types and incorporated within the ArcSWAT soil database to characterise each soil type. The soil parameters were defined based on field samples, literature, mathematical model and field observations for the catchment. The USLE soil erodibility K-factor was calculated according to a general equation developed by Williams et al. (1975) recommended by the input/output documentation of the model (Neitsch et al., 2010).

The land cover map was extracted from the European Project Corine Land Cover map (2000) with a resolution of
$100 \mathrm{~m}$. The 14 categories identified in the catchment were evaluated to assign an equivalent class in the SWAT2009 database (Fig. 2). Finally, the overlaid spatial input data lead to the definition of 853 HRUs within ArcSWAT.

Climate inputs available and used in this SWAT project were daily minimum and maximum temperature and rainfall data. They were based on measured data within or close to the region (Fig. 1). Data sources were obtained from the Spanish Governmental Meteorological Agency (AEMET, Agencia Estatal de Meteorología).

\subsubsection{Catchment parameterisations in SWAT}

The discharge of flow by the karst system outside the catchment was simulated by forcing SWAT to drain all simulated runoff from the headwater subcatchment limited by the Renclusa swallow hole (Fig. 1; Palazón and Navas, 2013). The drainage area limited by the karst system $\left(30 \mathrm{~km}^{2}\right)$ was excluded for the soil sediment production evaluation.

Reservoir parameterisations for Linsoles and Paso Nuevo reservoirs in SWAT were based on their technical characteristics (reservoir area and the principal and emergency spillway volumes) and simulated controlled release. The equilibrium sediment concentration of 0.058 and $0.065 \mathrm{~g} \mathrm{l}^{-1}$ for the small reservoirs Linsoles and Paso Nuevo were manually calibrated to produce simulated trap efficiency of 45 and $60 \%$, respectively.

To account for climate elevation gradients of the Linsoles catchment, 10 homogeneous elevation bands and their estimated altitudinal gradients on precipitation and temperature for the study area were defined in each subcatchment. The altitudinal temperature gradient (TLAPS: temperature lapse rate in SWAT) was set at $-5^{\circ} \mathrm{C} \mathrm{km}^{-1}$ (García-Ruiz et al., 2001) and the altitudinal precipitation gradient (PLAPS: precipitation lapse rate in SWAT) was set at $1000 \mathrm{~mm} \mathrm{~km}^{-1}$ for most of the catchment and was accordingly decreased by subcatchment in relation to the number of elevation bands above $2000 \mathrm{~m}$ a.s.l. It is widely documented that the precipitation altitudinal gradient decreases to almost half in the study area at heights above $2000 \mathrm{~m}$. Finally, the PLAPS for the subcatchments range from 550 to $1000 \mathrm{~mm} \mathrm{~km}^{-1}$.

Calibration of SWAT was necessary, as the model comprises a large number of parameters that define various catchment characteristics and processes. As the Benasque system is the headwater of the Barasona catchment, the calibrated parameters for the Barasona catchment, as validated for flow and sediment in previous work (Palazón and Navas, 2014), were used in this study. As no temperature index method or equivalent snow data of the study area were available, defining the snowfall-snowmelt processes in SWAT for this mountainous catchment was an important part of the calibration. The default SWAT values of the snow routine parameters were manually modified in such a way as to obtain resultant snowfall and snowmelt values in good agreement with 
the snow retention and snowmelt streamflow observed in the region.

The calibrated scenario was conducted over a period of 4 years (2003-2006) preceded by a 3-year model "warm-up" initialisation period. The model period was selected to include a variety of climatic and hydrological conditions.

\subsection{Sediment fingerprinting procedure}

The standard sediment source fingerprinting procedure is based on (i) a statistical analysis of difference in order to identify a subset of tracer properties that discriminate the sediment sources followed by (ii) the use of multivariate mixing models comprising a set of linear equations for each selected tracer property in order to estimate the proportional contributions from each source (Yu and Oldfield, 1989; Collins et al., 1997; Walden et al., 1997; Blake et al., 2012; Smith and Blake, 2014). Uncertainty in source estimates is quantified using a Monte Carlo routine that repeatedly solves the mixing model using random samples drawn from probability distributions derived for source groups (Franks and Rowan, 2000).

\subsubsection{Sediment and soil sampling}

To characterise the signatures of potential sediment source materials, representative sites were selected in areas where there was high potential sediment yield connectivity from hillslope to channel with easy access (Fig. 3). A total of 50 individual samples were collected, including 32 soil samples and 18 channel bed sediments. Twelve samples of sediment deposited in the reservoirs were collected to permit comparison of reservoir silt to sources. These comprised six individual samples from each of the two small headwater reservoirs. Sampling was done by using a cylindrical core $5 \mathrm{~cm}$ long and $6 \mathrm{~cm}$ in diameter.

Composite soil samples for this preliminary research were generated from undisturbed soils by four individual samples collected from 0 to $5 \mathrm{~cm}$ depth and combined in the field to form a single composite sample. The depth of sampling interval was selected because of stoniness and high surface soil roughness in the study soils. Of the soil samples, two were composite samples from Cambisols, three from Fluvisols and three composite samples from Kastanozems and Phaeozems. Leptosols were not sampled because in addition to being very poorly developed and shallow, they occupy areas of very high slope (more than $50 \%$ in areas with $>60 \%$ slope), which was difficult to access (Fig. 3). It was decided to concentrate efforts for this preliminary research on the better-developed soils of the catchment which were connected to the channel.

Exposed channel bed fine sediments were sampled as an intermediate target, as they represent mixed material delivered from the upstream catchment, stored within the system. They could also be considered a secondary source over a longer time frame. A field survey was carried out to select the sampling sites for collecting exposed channel bed samples in the four main tributaries to the Ésera River. In each tributary two locations were established upstream close to the headwater and downstream at a minimum distance of $3 \mathrm{~km}$ to the inflow in the Ésera River. From the eight selected locations, only three of them had fine exposed channel bed materials for sampling (Fig. 3). In each site a total of six samples were collected along transects $100 \mathrm{~m}$ long and mixed up to prepare three composite samples representative of the sediment deposited and being transported into the channel reach. In general, the Ésera River flows through blocky or rocky channels. Channel banks are either not developed or they are very local, with maximum river incisions of $10-15 \mathrm{~cm}$ in the soils of the valley bottoms and, therefore, they were not sampled.

Sediments from the Paso Nuevo and Linsoles reservoirs were sampled in accessible areas of the reservoir delta. In each reservoir, a composite sediment sample was prepared in the field, with a minimum of six fine sediment samples of exposed reservoir deposits. All samples were initially ovendried at $35^{\circ} \mathrm{C}$, gently disaggregated and sieved to $<63 \mu \mathrm{m}$ to isolate a standardised grain size fraction.

\subsubsection{Laboratory analyses}

Analysis of sample grain size was performed using a laser diffraction particle size analyser. Prior to analysis, organic matter was eliminated with an $\mathrm{H}_{2} \mathrm{O}_{2}(10 \%)$ digest heated to $80^{\circ} \mathrm{C}$. Samples were disaggregated with sodium hexametaphosphate $(40 \%)$, stirred for 2 hours and dispersed with ultrasound for a few minutes. Soil organic carbon content was analysed using a dry combustion method using a LECO RC-612 multiphase carbon analyser designed to differentiate forms of carbon by oxidation temperature (LECO, 1996). These analyses were performed on a subsample of the $<63 \mu \mathrm{m}$ fraction that had been ground to a very fine powder with a mortar and pestle.

Mass specific magnetic susceptibility $(\chi)$ was measured using a Bartington Instruments dual-frequency MS2B sensor that operates with an alternating current, producing an alternating magnetic field at $80 \mathrm{~A} \mathrm{~m}^{-1}$ (Bartington Instruments Ltd. 2000). The MS2B sensor can be operated at two different frequencies, at low frequency $0.47 \mathrm{kHz}(\mathrm{LF})$ and at high frequency $4.70 \mathrm{kHz}(\mathrm{HF})$. The $<63 \mu \mathrm{m}$ fraction of the samples were placed in $10 \mathrm{ml}$ sample containers and $\chi$ was measured at each frequency and the frequency dependence of susceptibility $\left(\chi_{\mathrm{FD}}\right)$ was obtained. Mass specific magnetic susceptibility at low $\left(\chi_{\mathrm{LF}}\right)$ and high $\left(\chi_{\mathrm{HF}}\right)$ frequency measurements was expressed as $10^{-8} \mathrm{~m}^{3} \mathrm{~kg}^{-1}$. In this study three measures of mass specific magnetic susceptibility were taken from each sample and the average was reported. The $\chi_{\text {FD }}$ was the percentage of difference between $\chi_{\mathrm{LF}}$ and $\chi_{\mathrm{HF}}$, therefore the $\chi_{\mathrm{HF}}$ was considered redundant and was not included in the statistical analysis of the fingerprinting procedure.

The analysis of the total elemental composition was carried out after total acid digestion with $\mathrm{HF}(48 \%)$ in a 




Figure 3. Distribution of soil and sediment samples in the Benasque catchment.

microwave oven (Navas and Machín, 2002). Samples were analysed for the following 28 elements: $\mathrm{Li}, \mathrm{K}, \mathrm{Na}$ (alkaline), $\mathrm{Be}, \mathrm{Mg}, \mathrm{Ca}, \mathrm{Sr}$ (light metals), $\mathrm{Cr}, \mathrm{Cu}, \mathrm{Mn}, \mathrm{Fe}, \mathrm{Al}$, $\mathrm{Zn}, \mathrm{Ni}, \mathrm{Co}, \mathrm{Cd}, \mathrm{Tl}, \mathrm{Bi}, \mathrm{V}, \mathrm{Ti}$ and $\mathrm{Pb}$ (heavy metals), B, Sb, As (metalloids), and P, S, Mo and Se. Analyses were performed in triplicate by inductively coupled plasma atomic emission spectrometry (ICP-AES) and resulting concentrations expressed in $\mathrm{mg} / \mathrm{kg}$. Those elements returning measurements below the detection limit $(\mathrm{Co}, \mathrm{Cd}$ and $\mathrm{Se})$ were excluded from the analysis. $\mathrm{P}$ was also excluded on the basis of the risk of non-conservative behaviour during downstream transport (Granger et al., 2007).

The methods used in the analysis of radionuclides are described in detail elsewhere (Navas et al., 2005a, b). Radionuclide activity concentrations in the soil samples were measured using a Canberra high resolution, low background, high-purity germanium coaxial gamma detector coupled to an amplifier and multichannel analyser. The detector had a relative efficiency of $50 \%$ and a resolution of $1.9 \mathrm{keV}$ (shielded to reduce background), and was calibrated using standard samples that had the same geometry as the measured samples. Subsamples of $50 \mathrm{~g}$ were loaded into plastic containers. Count times over $24 \mathrm{~h}$ provided an analytical precision of about $\pm 3-10 \%$ at the $95 \%$ level of confidence. Activities were expressed as $\mathrm{Bq} \mathrm{kg}^{-1}$ dry soil.

Gamma emissions of ${ }^{238} \mathrm{U},{ }^{226} \mathrm{Ra},{ }^{232} \mathrm{Th},{ }^{40} \mathrm{~K},{ }^{210} \mathrm{~Pb}$, and ${ }^{137} \mathrm{Cs}$ (in $\mathrm{Bq} \mathrm{kg}^{-1}$ air-dried soil) were measured in the bulk soil samples. Considering the appropriate corrections for laboratory background, ${ }^{238} \mathrm{U}$ was determined from the $63 \mathrm{keV}$ line of ${ }^{234} \mathrm{Th}$, the activity of ${ }^{226} \mathrm{Ra}$ was determined from the $352 \mathrm{keV}$ line of ${ }^{214} \mathrm{~Pb}$ (Van Cleef, 1994); ${ }^{210} \mathrm{~Pb}$ activity was determined from the $47 \mathrm{keV}$ photopeak, ${ }^{40} \mathrm{~K}$ from the $1461 \mathrm{keV}$ photopeak; ${ }^{232} \mathrm{Th}$ was estimated using the $911 \mathrm{keV}$ photopeak of ${ }^{228} \mathrm{Ac}$, and ${ }^{137} \mathrm{Cs}$ activity was determined from the $661.6 \mathrm{keV}$ photopeak. The measured activity concentration of ${ }^{210} \mathrm{~Pb}$ (half-life $=22.26 \mathrm{yr}$ ) is an integration of the "in 
situ" geogenic component from decay of ${ }^{226} \mathrm{Ra}$ within the material (Appleby and Oldfield, 1992) and the fallout component derived via diffusion of ${ }^{222} \mathrm{Rn}$ into the atmosphere and subsequent deposition of fallout ${ }^{210} \mathrm{~Pb}_{\mathrm{ex}}$. Spectrometric measurements were performed a month after the samples were sealed which ensured a secular equilibrium between ${ }^{222} \mathrm{Rn}$ and ${ }^{226} \mathrm{Ra}$. The ${ }^{210} \mathrm{~Pb}_{\text {ex }}$ activities were estimated from the difference between the total ${ }^{210} \mathrm{~Pb}$ activity and the ${ }^{226} \mathrm{Ra}$ activity.

\subsubsection{Statistical analysis for source discrimination}

Examination of the range of source and sediment tracer concentrations is an important assessment of the conservative behaviour of each tracer property (Martínez-Carreras, 2010a; Wilkinson et al., 2012; Smith and Blake, 2014). In this study, the range of source tracer concentrations was compared to the range in sediment concentrations for each target downstream sediment sample (reservoirs and channel beds), with those tracer properties falling outside the range in source values being removed from subsequent analysis.

Statistical analysis of remaining tracer properties first involves using the nonparametric Kruskal-Wallis $H$-test to identify and eliminate redundant tracer properties that do not exhibit a significant difference between source categories (Collins and Walling, 2002). It tests the null hypothesis that tracer properties exhibit no significant differences between source categories. Larger differences between categories generated greater $H$-test statistics. A stepwise Discriminant Function Analysis (DFA) was used to test the ability of the tracer properties passing the Kruskal-Wallis Htest to confirm the existence of inter-category contrast. The DFA select an optimum composite fingerprint that comprises the minimum number of tracer properties that provide the greatest discrimination between the analysed source materials based on the minimisation of Wilks' lambda. The lambda value approaches zero as the variability within source categories is reduced relative to the variability between categories based on the entry or removal of tracer properties from the analysis. The results of the DFA are used to examine the proportion of samples accurately classified into the correct source groups.

\subsubsection{Multivariate mixing model}

The relative contribution of each potential sediment source was assessed by a Monte Carlo mixing model using a new data processing methodology to obtain proportional source contributions for the reservoir sediment samples. Similar to other approaches (e.g. Evrard et al., 2011), the model seeks to solve the system of linear equations by means of mass balance equations represented by

$\sum_{j=1}^{m} a_{i, j} \cdot x_{j}=b_{i}$, while satisfying the following constraints:

$$
\begin{aligned}
& \sum_{j=1}^{m} x_{j}=1 \\
& 0 \leq x_{j} \leq 1
\end{aligned}
$$

where $b_{i}$ is the value of tracer property $i(i=1$ to $n)$ in the reservoir sediment sample, $a_{i, j}$ is the mean concentration of tracer property $i$ in source type $j\left(j=1\right.$ to $m$ ), $x_{j}$ is the unknown relative weighting contribution of source type $j$ to the suspended sediment sample, $m$ is the number of potential source types, and $n$ is the number of tracer properties selected by the DFA.

The new approach adopted here used a Monte Carlo sampling routine to generate uniformly distributed weights that sum unity to identify the possible source contributions. The model was written in the $\mathrm{C}$ programming language and designed to deliver a user-defined number of best possible solutions over a defined number of iterations. The unique solution from the generated iterations for each sediment sample was characterised by the mean weighting source contribution, the standard deviation of the user-defined solutions and their lower goodness of fit (GOF) index (Motha et al., 2003) defined by

$\mathrm{GOF}=1-\frac{1}{n} \times\left(\sum_{i=1}^{n} \frac{\left|b_{i}-\sum_{j=1}^{m} x_{j} a_{i, j}\right|}{\Delta_{i}}\right)$,

where $\Delta_{i}$ is used as correction factor to normalize the tracer properties ranges. This method is argued to guarantee a similar set of representative solutions in all unmixing cases based on likelihood of occurrence. Source samples for the different potential sediment sources of the drainage basin were compared with samples from the reservoirs and from the channel bed sediments using an optimum composite fingerprint defined by the DFA in each case. In both cases, the model was configured to select the 10 results with the highest GOF obtained from $10^{6}$ generated random positive solutions using multiple start values for each sediment target samples.

\section{Results}

\subsection{Soil-specific sediment yields by the SWAT model}

The temporal distribution of the observed and simulated flow and sediment yields for the Linsoles gauge station agreed with the simulated data (Fig. $4 \mathrm{a}$ and b). The average simulated sediment yield that inflow to Paso Nuevo and Linsoles reservoirs were 12543 and 26145 t year $^{-1}$, respectively. The simulated streamflow of the study period (2003-2006) showed the characteristics of the nivo-pluvial regime. The monthly inflow discharge at the Linsoles reservoir performed a satisfactory Nash-Sutcliffe coefficient of 0.62 (Nash and Sutcliffe, 1970). 


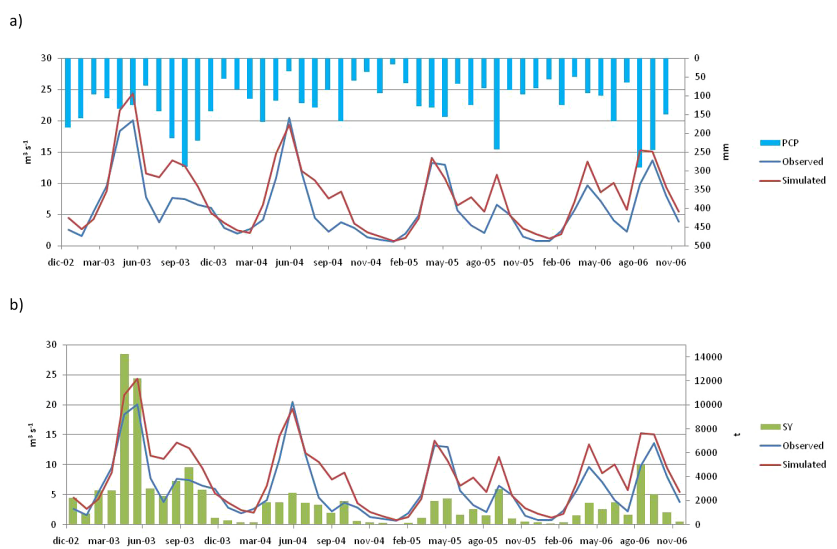

Figure 4. Compared monthly hydrographs simulated by SWAT for the Linsoles reservoir inflow gauge station, with (a) simulated monthly rainfall for the Benasque catchment and (b) simulated monthly sediment yields (SY; t).

Table 2. Soil-specific sediment yields (SSY; tha ${ }^{-1}$ year $^{-1}$ ) simulated by SWAT for the period 2003-2006.

\begin{tabular}{llllll}
\hline & Period & 2003 & 2004 & 2005 & 2006 \\
\hline Cambisols & 1.56 & 3.73 & 0.44 & 0.68 & 1.41 \\
Fluvisols & 0.16 & 0.46 & 0.01 & 0.02 & 0.15 \\
Kastanozems & 0.57 & 1.49 & 0.08 & 0.04 & 0.68 \\
Leptosols & 0.55 & 1.58 & 0.45 & 0.04 & 0.12 \\
Phaeozems & 0.10 & 0.28 & 0.02 & 0.02 & 0.07 \\
\hline
\end{tabular}

Application of the SWAT model for the Benasque catchment enabled investigation of the sediment yields generated from the different soil types and their temporal dynamics. The soil-specific sediment yield $\left(\mathrm{t} \mathrm{ha}^{-1}\right.$ year $\left.^{-1}\right)$ showed substantial differences in production amounts (Table 2). The greatest modelled specific sediment yield was produced from Cambisols, followed by Kastanozems and then Leptosols. The modelled specific sediment yield from Cambisols was three times greater than from Kastanozems, thus suggesting that these are the main soil source of sediments to the Ésera River. The lowest sediment production was from Fluvisols and Phaeozems.

In general, the snowmelt (together with the spring season) provided the highest modelled soil-specific sediment yield (followed by the autumn season), whereas the lowest soilspecific sediment yield was provided in summer and winter (Fig. 5). Cambisols, Kastanozems, Leptosols and Phaeozems produced the highest specific sediment yield in spring and autumn, whereas the lowest was during summer and winter. However, Fluvisols showed a different pattern, producing its lowest specific sediment yield in spring.

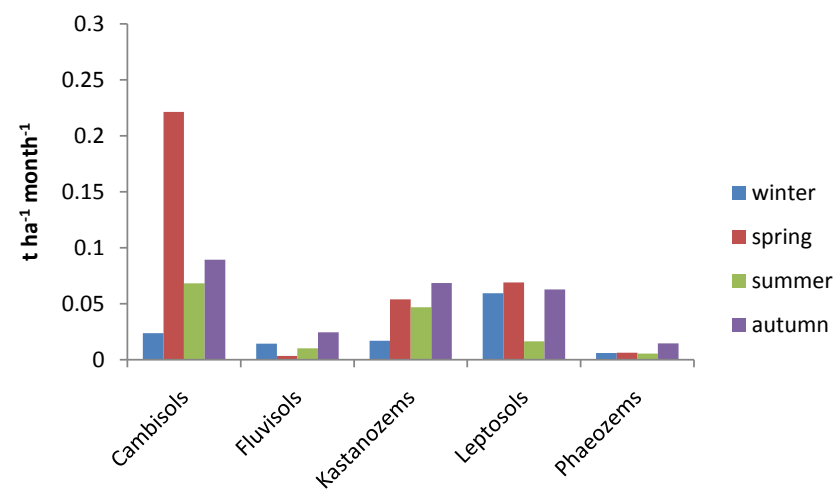

Figure 5. Seasonal distribution of simulated soil-specific sediment yield ( $\mathrm{tha}^{-1}$ month $^{-1}$ ).

\subsection{Soil and sediment source contributions}

In this study, two downstream sediment targets were evaluated against sources. The first option involved the sediment contributions from soils to the reservoir sediments and the second one considered channel bed sediments as mixed sediment samples. Proportional soil source contributions to sediment samples were estimated for the Paso Nuevo and Linsoles reservoirs and for the channel bed sediments.

To identify main sources of sediments, firstly, the conservative behaviour of the properties (Table 3) for the selection of the optimum fingerprint was considered for both options. ${ }^{210} \mathrm{~Pb}_{\mathrm{ex}}$ was excluded as a sediment source fingerprint because sediments deposited in the reservoir will contain both ${ }^{210} \mathrm{~Pb}_{\mathrm{ex}}$ incorporated into the sediment by direct fallout to the reservoir and that associated with sediment eroded from the upstream catchment. SOC and grain size fractions are considered non-conservative properties due to the influence of sorting processes and therefore, they were also excluded from the analyses (Koiter et al., 2013).

The comparison of the range in tracer properties concentrations for source and sediment samples resulted in the exclusion of different properties in each target option for the statistical analysis. As intermediate targets, the property concentrations of the channel bed sediments were more limited than the property concentrations of the reservoir sediments, resulting in the exclusion of most properties for the channel beds and making fingerprinting challenging. For the reservoirs, the comparison of the ranges in tracer property concentrations for sources and sediment samples resulted in the exclusion of ${ }^{137} \mathrm{Cs},{ }^{226} \mathrm{Ra}, \mathrm{Al}, \mathrm{B}, \mathrm{Bi}, \mathrm{Cu}, \mathrm{Mg}, \mathrm{Mo}, \mathrm{S}, \mathrm{Tl}$, and Ti. In addition to this last option, the range of the tracer properties for the channel bed sediments resulted in the exclusion of ${ }^{40} \mathrm{~K}, \mathrm{FD}, \mathrm{As}, \mathrm{Fe}$ and $\mathrm{Sr}$, but in this case $\mathrm{Tl}$ was included for the statistical analysis. The above suggests that sorting may have a differential effect on tracer properties; the future targeting of discrete size fractions of fine material in both source and sink may help with this (cf. Motha et al., 
Table 3. Statistics measures of the tracer properties for the potential sediment sources (KSPH: Kastanozems/Phaeozems; FL: Fluvisols; and CM: Cambisols) and targets (units: textural classes: \%; radionuclide: $\mathrm{Bq} \mathrm{kg}^{-1}$; low frequency mass specific magnetic susceptibility $10^{-8} \mathrm{~m}^{3} \mathrm{~kg}^{-1}$ and magnetic susceptibility frequency dependence $\%$; total elemental composition: $\mathrm{mg} \mathrm{kg}^{-1}$ ).

\begin{tabular}{|c|c|c|c|c|c|c|c|c|c|c|c|c|c|c|c|c|c|}
\hline & $\begin{array}{l}\text { KSPH } \\
\mathrm{m}\end{array}$ & $\begin{array}{l}n=3 \\
\text { sd }\end{array}$ & $\min$ & $\max$ & $\begin{array}{l}\mathrm{FL} \\
\mathrm{m}\end{array}$ & $\begin{array}{l}n=3 \\
\text { sd }\end{array}$ & $\min$ & $\max$ & $\begin{array}{l}\mathrm{CM} \\
\mathrm{m}\end{array}$ & $\begin{array}{l}n=2 \\
\text { sd }\end{array}$ & $\min$ & $\max$ & $\mathrm{CbS} 1$ & $\mathrm{CbS} 2$ & $\mathrm{CbS} 3$ & PNR & LR \\
\hline Sand & 11.2 & 4.3 & 6.2 & 14.1 & 27.5 & 7.0 & 20.0 & 33.8 & 16.5 & 0.9 & 15.8 & 17.1 & 1.9 & 29.9 & 32.2 & 15.5 & 22.2 \\
\hline Silt & 71.7 & 1.5 & 70.3 & 73.2 & 65.7 & 6.0 & 60.0 & 72.0 & 72.8 & 2.2 & 71.2 & 74.3 & 79.5 & 66.4 & 62.4 & 78.7 & 70.4 \\
\hline Clay & 17.2 & 3.0 & 15.3 & 20.6 & 6.9 & 1.0 & 6.3 & 8.0 & 10.8 & 3.1 & 8.7 & 13.0 & 18.6 & 3.7 & 5.4 & 5.8 & 7.5 \\
\hline${ }^{40} \mathrm{~K}$ & 712.3 & 26.4 & 682.0 & 730.0 & 773.0 & 30.3 & 749.0 & 807.0 & 699.5 & 34.6 & 675.0 & 724.0 & 705.0 & 666.0 & 851.0 & 698.0 & 717.0 \\
\hline${ }^{137} \mathrm{Cs}$ & 136.2 & 66.2 & 79.5 & 209.0 & 62.0 & 10.7 & 50.9 & 72.3 & 61.4 & 18.0 & 48.7 & 74.1 & 11.9 & 0.0 & 5.7 & 2.9 & 94.9 \\
\hline${ }^{210} \mathrm{~Pb}_{\mathrm{ex}}$ & 258.0 & 159.4 & 163.8 & 442.0 & 264.1 & 81.6 & 180.9 & 343.9 & 145.4 & 31.0 & 123.4 & 167.3 & 80.9 & 0.0 & 30.0 & 19.8 & 385.3 \\
\hline${ }^{226} \mathrm{Ra}$ & 38.0 & 4.4 & 33.0 & 41.2 & 58.2 & 6.6 & 51.1 & 64.1 & 50.7 & 5.7 & 46.6 & 54.7 & 94.1 & 86.8 & 46.3 & 64.6 & 63.7 \\
\hline${ }^{232} \mathrm{Th}$ & 75.3 & 14.1 & 59.9 & 87.7 & 84.9 & 8.8 & 78.7 & 94.9 & 60.2 & 16.1 & 48.8 & 71.6 & 85.6 & 72.6 & 73.4 & 62.4 & 77.7 \\
\hline${ }^{238} \mathrm{U}$ & 53.0 & 4.9 & 49.3 & 58.5 & 218.7 & 71.4 & 139.0 & 277.0 & 162.4 & 135.2 & 66.8 & 258.0 & 133.0 & 105.0 & 63.1 & 81.0 & 248.0 \\
\hline SOC & 12.7 & 3.9 & 9.4 & 17.0 & 4.0 & 1.0 & 2.9 & 4.9 & 9.9 & 1.3 & 9.0 & 10.8 & 1.5 & 0.3 & 0.7 & 1.0 & 4.9 \\
\hline $\mathrm{LF}$ & 108.6 & 62.2 & 38.3 & 156.6 & 25.0 & 1.9 & 23.7 & 27.2 & 43.6 & 46.8 & 10.5 & 76.7 & 50.3 & 11.2 & 12.3 & 13.4 & 31.8 \\
\hline FD & 8.9 & 2.9 & 5.5 & 10.5 & 3.7 & 2.6 & 1.7 & 6.6 & 5.2 & 3.3 & 2.9 & 7.6 & 1.6 & 5.4 & 6.5 & 5.2 & 4.1 \\
\hline $\mathrm{Al}$ & 51140.0 & 5389.7 & 44970.0 & 54930.0 & 59326.7 & 4787.0 & 54860.0 & 64380.0 & 42220.0 & 8103.4 & 36490.0 & 47950.0 & 60040.0 & 55840.0 & 50100.0 & 69640.0 & 52220.0 \\
\hline As & 102.3 & 61.8 & 41.9 & 165.4 & 31.9 & 3.7 & 28.3 & 35.6 & 28.7 & 3.2 & 26.5 & 31.0 & 44.4 & 31.9 & 17.8 & 26.7 & 87.2 \\
\hline $\mathrm{Be}$ & 2.1 & 0.2 & 1.9 & 2.3 & 2.6 & 0.5 & 2.0 & 3.0 & 1.6 & 0.0 & 1.6 & 1.6 & 2.2 & 1.8 & 2.4 & 1.8 & 2.7 \\
\hline $\mathrm{Bi}$ & 30.8 & 3.8 & 26.4 & 33.2 & 34.4 & 3.7 & 30.6 & 37.9 & 32.1 & 4.0 & 29.3 & 35.0 & 49.6 & 39.6 & 35.8 & 41.4 & 39.0 \\
\hline B & 1873.3 & 348.5 & 1500.0 & 2190.0 & 2240.0 & 170.9 & 2060.0 & 2400.0 & 2725.0 & 516.2 & 2360.0 & 3090.0 & 3140.0 & 3010.0 & 1930.0 & 4230.0 & 1130.0 \\
\hline $\mathrm{Ca}$ & 5002.7 & 4103.7 & 2312.0 & 9726.0 & 21356.7 & 4270.8 & 17350.0 & 25850.0 & 8532.0 & 5922.7 & 4344.0 & 12720.0 & 39280.0 & 46540.0 & 9612.0 & 41150.0 & 25580.0 \\
\hline $\mathrm{Cd}$ & 0.6 & 0.1 & 0.5 & 0.8 & 1.0 & 0.2 & 0.8 & 1.2 & 0.7 & 0.1 & 0.6 & 0.7 & 1.3 & 1.2 & 0.4 & 1.0 & 1.4 \\
\hline Co & 0.4 & 0.0 & 0.4 & 0.4 & 18.0 & 15.3 & 0.4 & 28.2 & 8.3 & 2.8 & 6.3 & 10.3 & 5.5 & 8.3 & 10.6 & 6.7 & 28.3 \\
\hline $\mathrm{Cr}$ & 100.2 & 10.4 & 90.5 & 111.2 & 79.0 & 12.5 & 71.3 & 93.5 & 59.2 & 2.4 & 57.5 & 60.9 & 84.0 & 64.8 & 90.0 & 67.9 & 98.6 \\
\hline $\mathrm{Cu}$ & 24.3 & 7.5 & 16.1 & 30.6 & 29.9 & 4.8 & 24.5 & 33.9 & 21.3 & 0.3 & 21.1 & 21.5 & 41.6 & 42.5 & 25.0 & 37.0 & 31.4 \\
\hline $\mathrm{Fe}$ & 48646.7 & 8073.5 & 39920.0 & 55850.0 & 47980.0 & 5508.9 & 43830.0 & 54230.0 & 41715.0 & 9397.4 & 35070.0 & 48360.0 & 68040.0 & 49840.0 & 44390.0 & 51710.0 & 47260.0 \\
\hline $\mathrm{K}$ & 14146.7 & 993.2 & 13000.0 & 14740.0 & 14710.0 & 1022.4 & 13530.0 & 15330.0 & 9969.5 & 1429.1 & 8959.0 & 10980.0 & 13890.0 & 13680.0 & 14780.0 & 14610.0 & 11710.0 \\
\hline $\mathrm{Li}$ & 69.9 & 3.3 & 67.2 & 73.6 & 73.1 & 25.8 & 50.9 & 101.4 & 68.7 & 22.0 & 53.2 & 84.2 & 83.7 & 63.5 & 92.5 & 70.8 & 76.9 \\
\hline $\mathrm{Mg}$ & 2735.9 & 2951.1 & 897.8 & 6140.0 & 7791.0 & 1674.9 & 6594.0 & 9705.0 & 3829.0 & 1137.0 & 3025.0 & 4633.0 & 5214.0 & 5147.0 & 1232.0 & 3593.0 & 9815.0 \\
\hline $\mathrm{Mn}$ & 975.2 & 460.7 & 653.4 & 1503.0 & 707.4 & 71.3 & 634.2 & 776.7 & 634.5 & 513.4 & 271.4 & 997.5 & 389.5 & 478.2 & 417.9 & 526.8 & 918.1 \\
\hline Mo & 1.4 & 0.5 & 1.0 & 1.9 & 1.6 & 0.4 & 1.2 & 1.9 & 1.8 & 0.1 & 1.7 & 1.9 & 6.5 & 5.5 & 1.2 & 4.9 & 1.6 \\
\hline $\mathrm{Na}$ & 7124.0 & 926.1 & 6279.0 & 8114.0 & 7778.3 & 585.7 & 7114.0 & 8220.0 & 5886.5 & 734.7 & 5367.0 & 6406.0 & 6708.0 & 6102.0 & 6219.0 & 6212.0 & 7659.0 \\
\hline $\mathrm{Ni}$ & 39.0 & 8.3 & 31.2 & 47.7 & 47.0 & 10.3 & 38.2 & 58.3 & 30.0 & 6.3 & 25.5 & 34.5 & 50.8 & 49.9 & 38.7 & 47.0 & 50.9 \\
\hline $\mathrm{Pb}$ & 34.9 & 7.0 & 26.9 & 39.8 & 69.8 & 20.9 & 45.8 & 84.7 & 105.0 & 92.7 & 39.5 & 170.5 & 41.7 & 40.6 & 33.2 & 42.8 & 83.1 \\
\hline $\mathrm{P}$ & 1161.3 & 124.9 & 1023.0 & 1266.0 & 1286.0 & 172.0 & 1088.0 & 1399.0 & 1704.0 & 888.1 & 1076.0 & 2332.0 & 846.5 & 1132.0 & 960.9 & 1019.0 & 1443.0 \\
\hline $\mathrm{Sb}$ & 11.7 & 4.4 & 7.7 & 16.4 & 3.3 & 0.8 & 2.8 & 4.1 & 2.1 & 0.8 & 1.5 & 2.7 & 2.6 & 4.3 & 4.3 & 4.6 & 3.2 \\
\hline $\mathrm{Se}$ & 1.4 & 0.9 & 0.4 & 2.3 & 1.6 & 0.7 & 1.1 & 2.4 & 1.7 & 0.4 & 1.4 & 2.0 & 0.4 & 1.3 & 2.4 & 2.4 & 2.9 \\
\hline S & 705.7 & 147.5 & 539.3 & 820.2 & 912.9 & 82.4 & 846.2 & 1005.0 & 806.0 & 74.6 & 753.2 & 858.7 & 1054.0 & 3356.0 & 920.3 & 1631.0 & 821.5 \\
\hline $\mathrm{Sr}$ & 60.0 & 19.2 & 47.6 & 82.1 & 158.7 & 16.7 & 144.7 & 177.1 & 74.7 & 47.8 & 40.9 & 108.5 & 213.0 & 170.2 & 69.9 & 147.1 & 152.1 \\
\hline $\mathrm{Ti}$ & 5723.3 & 714.5 & 5170.0 & 6530.0 & 5336.7 & 250.1 & 5090.0 & 5590.0 & 5235.0 & 530.3 & 4860.0 & 5610.0 & 4400.0 & 4500.0 & 5710.0 & 5090.0 & 4530.0 \\
\hline $\mathrm{Tl}$ & 40.4 & 10.9 & 33.9 & 52.9 & 57.3 & 5.1 & 51.9 & 62.1 & 45.3 & 11.9 & 36.9 & 53.7 & 60.9 & 52.5 & 34.7 & 48.5 & 69.1 \\
\hline V & 124.8 & 13.9 & 115.4 & 140.8 & 118.9 & 25.8 & 94.7 & 146.0 & 111.3 & 5.9 & 107.1 & 115.4 & 175.9 & 143.5 & 137.5 & 153.3 & 145.1 \\
\hline $\mathrm{Zn}$ & 102.9 & 34.6 & 80.6 & 142.7 & 243.7 & 75.5 & 157.4 & 297.9 & 300.3 & 148.4 & 195.4 & 405.2 & 110.7 & 128.5 & 94.6 & 129.7 & 282.9 \\
\hline
\end{tabular}

m: mean; sd: standard deviation; min: minimum; max: maximum; SOC: soil organic carbon; LF: low frequency mass specific magnetic susceptibility; FD: magnetic susceptibility frequency dependence; CbS x: channel bed sediment number x; PNR: Paso Nuevo reservoir; LR: Linsoles reservoir.

2003). For both options, the Kruskal-Wallis $H$-test resulted in the null identification of tracer properties to discriminate between sediment sources (significance $p<0.05$ ). However, based on Wilks' lambdas (Table 4) and the $100 \%$ percentage of correctly classified sources, apparently good source discrimination was achieved. The DFA led to the selection of $\mathrm{K}$, $\mathrm{Sr},{ }^{238} \mathrm{U}, \mathrm{Sb}$ and LF as the optimum source fingerprinting for the reservoir sediments and $\mathrm{K},{ }^{238} \mathrm{U}, \mathrm{Al}, \mathrm{Sb}$ and $\mathrm{LF}$ as the optimum source fingerprinting for the channel bed sediments.

The unmixing model used all tracer properties that were selected by the DFA for each target option, and the goodness of fit (GOF) of each solution was calculated for each sediment sample. Uncertainty is reported as the standard deviation for each set of solutions. The outputs of the mixing model for the channel bed sediments showed good consistency, all outputs being very close and systematically within a range of $<1 \%$ to the mean value. Mean proportional contributions from Kastanozem/Phaeozem, Cambisol and Fluvisol sources varied between sediment samples (Table 5). Sample GOFs were all > $71 \%$ (Table 5), with the lower val- ues suggesting some scope for refinement of source characterisation. Channel bed sediment sample 3 had the lowest mean GOF and, reassuringly, the largest predicted uncertainty. Channel bed sediment samples 1 and 2, located close to the Ésera River, had similar contributions. In contrast, channel bed sediment at the headwater of the Ésera tributary (site 3) had the lowest Fluvisol and greatest Cambisol contributions. The preliminary results using this new data processing methodology for samples collected in the channel beds of the tributaries suggest that the Fluvisol soil was the main potential source of sediments for sample sites 1 and 2, and Cambisols were the main potential source of sediments for sample site 3 .

The outputs of the mixing model for reservoir sediments also showed consistency with all outputs being very close and systematically within a range of $<1 \%$ of their mean value. Mean proportional contributions from Kastanozem/Phaeozem, Cambisol and Fluvisol sources varied between sediment samples, and both reservoir sample sets had GOF $>83 \%$ (Table 5). The preliminary results suggest 
Table 4. Results of the stepwise discriminant function analysis to identify the optimum composite fingerprint for the assessed fingerprinting options.

\begin{tabular}{llll}
\hline $\begin{array}{l}\text { Fingerprinting } \\
\text { target options }\end{array}$ & $\begin{array}{l}\text { Fingerprint } \\
\text { property added }\end{array}$ & $\begin{array}{l}\text { Wilk's } \\
\text { lambda }\end{array}$ & Significance \\
\hline Channel bed sediment samples & $\mathrm{K}$ & 0.1677 & 0.0115 \\
& ${ }^{238} \mathrm{U}$ & 0.0273 & 0.0032 \\
& $\mathrm{Al}$ & 0.0003 & 0.0001 \\
& $\mathrm{Sb}$ & 0.0001 & 0.0006 \\
& $\mathrm{LF}$ & 0.000001 & 0.0046 \\
& $\mathrm{~K}$ & 0.1677 & 0.0115 \\
Reservoirs samples & $\mathrm{Kr}$ & 0.0228 & 0.0023 \\
& $238 \mathrm{U}$ & 0.0010 & 0.0003 \\
& $\mathrm{Sb}$ & 0.0001 & 0.0006 \\
& $\mathrm{LF}$ & 0.000001 & 0.0055 \\
\hline
\end{tabular}

Table 5. Mean percentages of GOF and source contributions (standard deviations) from the multivariate mixing model for Kastanozem/Phaeozem (KSPH), Fluvisol (FL), and Cambisol (CM) sources to the Paso Nuevo and Linsoles reservoirs and channel bed sediments (CbS) samples.

\begin{tabular}{llllll}
\hline Fingerprinting target options & Samples & GOF & KSPH & FL & CM \\
\hline Channel bed sediment samples & CbS 1 & 84 & $27(0)$ & $59(0)$ & $14(0)$ \\
& CbS 2 & 83 & $15(0)$ & $66(0)$ & $19(0)$ \\
& CbS 3 & 71 & $19(0)$ & $36(0)$ & $44(0)$ \\
\hline Reservoir samples & Paso Nuevo & 84 & $0(0)$ & $92(0)$ & $8(0)$ \\
& Linsoles & 83 & $7(0)$ & $87(0)$ & $6(0)$ \\
\hline
\end{tabular}

the Fluvisol is the main potential source of sediments to the reservoirs. The Paso Nuevo reservoir sample had the lowest mean GOF. Kastanozem/Phaeozem soil sources apparently contributed to the Linsoles reservoir, whereas no contribution from this source was made to the Paso Nuevo. For both reservoirs, Fluvisols were identified as the main source, contributing eight times more than the other sources.

\section{Discussion}

The sediment fingerprinting results suggested that at the time of sampling the Fluvisols were the main contributing source. In contrast, the SWAT model identified Cambisols as the main potential source of sediment of the Benasque catchment with the highest specific sediment yields, and Phaeozems and Fluvisols were identified as the lowest sediment contributors. The greater modelled stability of Phaeozems can be linked to their mostly forested vegetation cover and location in areas with the lowest slope ranges at the bottom of the catchment, leading to a low simulation of specific sediment yield. Fluvisols also occupy level surfaces and are covered by grass, hence the apparent stability within the model. Modelled winter sediment production from Leptosols is driven by their lo- cation on steep slopes and in areas with a high precipitation under the $0^{\circ} \mathrm{C}$ isotherm. In addition to receiving relatively more simulated rainfall than the other soils, runoff was especially high in the wettest year of the period (2003).

Soil temperature below $0{ }^{\circ} \mathrm{C}$ and snow cover limited sediment yields and streamflows in winter. The presence of snow cover restricted soil erosion and sediment flux. The differences between observed and simulated hydrographs (Fig. 4) for the Linsoles gauge station show a general overestimation of the related autumn streamflows by the model that might be due to limitations in the climate characterisation for the highly variable climatic characteristics of the Benasque catchment. In addition, the simulated monthly discharge of the Paso Nuevo reservoir may contribute to amplify these differences.

In addition to differences between the models WATEM/SEDEM and SWAT, dissimilarities in subcatchment configuration, time and land cover units did not enable us to directly compare sediment productions from the study by Alatorre et al. (2010) and our study. However, landuse/land-cover-specific sediment yields recorded in Alatorre et al. (2010) are of the same order of magnitude as the simulated specific sediment yields produced from the soils in our study. 
Differences in discriminant tracer properties selected for channel and reservoir sediments were a consequence of differences in tracer ranges. This suggests additional work is required to characterise the sources and that attention also needs to be paid to the potential influence of sorting and sediment storage on signature modification. Given the spatial distribution of soil types in the catchment, less variation in concentrations of tracer properties in channel bed sediments might be expected compared to in-reservoir sediments. Furthermore, the highly dynamic fluvial systems in the catchment, together with the location of the samples within the reservoirs, might restrict representation in the fingerprinting procedure of the finer sediments that can be exported out of the reservoir or located at the inner parts of the reservoir in the delta dam. The influence of grain size on properties requires attention wherein it is noted that sorting may increase or decrease the concentration of tracer properties, depending on mineralogical controls on particle size (Smith and Blake, 2014).

Differences in sediment apportionment results appear to be due to local fluvial dynamics and proximity of soil underlying the different upstream sections of their contributing areas. The contribution of Fluvisols to channel bed sediment sample 3, for example, was lower than for the other channel bed sediment samples because of the low extension of Fluvisols upstream. Minor differences in soil apportionments between the channel bed sediments could be related to different percentages of slopes and soil sources in their contributing areas (Fig. 3) but given the low GOF in some instances, additional work to refine source signatures is required. Paso Nuevo reservoir has a higher fluvial dynamic with more steep slopes and a greater percentage of Cambisols than the Linsoles reservoir (Table 1). In addition, the Paso Nuevo subcatchment received greater precipitation inputs because of the altitudinal climatic gradients of the catchment. The short sediment residence time in the channels observed in the catchment, with mostly clean blocky channel beds, supports the Fluvisol source contributions for all samples collected from material in storage. Furthermore, the highest apportionments from Fluvisols in these assessments suggest that stream connectivity is a main control of sediment input to the channel and that the more proximal sources are only connected to the channel at times of high flow when material is conveyed efficiently through the system.

Contributions from Cambisols remain important in many samples bearing in mind that without load or spatial loading data, proportions must be compared with caution (Smith et al., 2011). The differences in Fluvisol contributions between tracer and SWAT model outputs could also be due to the difference in the temporal and spatial scale of the procedures. The temporal discrepancy requires further investigation, e.g. through fingerprinting analysis of the temporal sequence within the sedimentary record of sediments from the middle of the reservoir. The spatial discrepancy was related to the resolution of SWAT soil inputs that could not reflect a detailed soil distribution extent and might not account for all soil erosion processes. Fluvisols occupy the bottoms of the glacially formed valleys and more than $85 \%$ of their surfaces have a slope range of between 0 and $20 \%$ in SWAT. The drainage of these relatively flat surfaces is done by small streams that concentrate runoff from the steep slopes (Fig. 3). Therefore, the erodibility of Fluvisols could be undervalued by the SWAT model. The absence of Leptosols for the fingerprinting approach represented a limitation but it should be noted that Leptosols are not the most abundant soil type in the catchment and connectivity is poor. In the catchment there are intermediate sediment storages in the form of small depressions, perched flat areas and dense vegetation cover that favours sediment retention (Alatorre et al., 2010; Navas et al., 2014) and the nature of the material in storage requires investigation. Furthermore, Fluvisols found at the foot of steep slopes where Leptosols are developed are sinks of sediments coming from Leptosols. These internal hillslope linkages require investigation.

In general, for both procedures sediment land cover sources were the most evaluated sediment sources in the literature (e.g. Martinez-Carreras et al., 2010b; Smith and Blake, 2014; Collins et al., 2013), though, discrimination of the soil sources with the fingerprinting procedure was possible for the alpine Benasque catchment because of its distinctive soil characteristics.

\section{Conclusions}

The SWAT model outputs identified Cambisols as the main soil source of sediment and the spring season as the time of peak sediment production in the Benasque catchment. The fingerprinting approach, in contrast, suggested that Fluvisols were the main contributing source to the sediment accumulated in the reservoirs and most of the channel bed sediments, implying that source area connectivity was a key factor and perhaps that during large events, material delivered from more proximal sources is conveyed efficiently through the system, with limited inputs to storage. Suspended sediment sampling through the year is required to test this hypothesis.

The SWAT sediment production assessment was dependent on the spatial and temporal distribution of a large number of input data, and topographic controls are an important factor. The fingerprinting approach was dependent on the discriminatory power of the analysed properties from the selected sources which in turn appear to be controlled by a sorting effect that require a refined sample preparation approach and consideration of discrete particle size fractions.

The combined use of the SWAT model and sediment fingerprinting in the study of soil erosion processes for the alpine Benasque catchment provided information from two temporal views, continuous and instantaneous. The SWAT model provided information, quantification and identification 
of the sediment production as well as its temporal dynamic evolution of the individual selected soil sediment sources based on factors such as runoff energy, soil erodibility, slope steepness and cover factor (MUSLE), which correspond to flow volume within the channel on a given day. In contrast, the fingerprinting approach provided information about "instantaneous" sediment source contributions to the assessed sediments from the reservoirs and channels - a "snapshot" of the sources deposited and retained under the most recent hydrological regime.

These initial findings demonstrate that a combined fingerprinting and modelling approach can offer insights into the temporal patterns of sediment delivery to reservoirs and the channel networks in alpine environments.

Acknowledgements. This research was funded by the EROMED project (CGL2011-25486).

Edited by: M. Oliva

\section{References}

Abbaspour, K. C., Yang, J., Maximov, I., Siber, R., Bogner, K., Mieleitner, J., Zobrist, J., and Srinivasan, R.: Modelling hydrology and water quality in the pre-Alpine/Alpine Thur watershed using SWAT, J. Hydrol., 333, 413-430, 2007.

Alatorre, L. C., Beguería, S., and García-Ruiz, J. M.: Regional scale modeling of hillslope sediment delivery: A case study in the Barasona Reservoir watershed (Spain) using WATEM/SEDEM, J. Hydrol., 391, 109-123, 2010.

Alewell, C., Meusburger, K., Brodbeck, M., and Bänninger, D.: Methods to describe and predict soil erosion in mountain regions, Landscape Urban Plan., 88, 46-53, 2008.

Appleby, P. G. and Oldfield, F.: Application of lead-210 to sedimentation studies, in: Uranium-Series Disequilibrium: Application to Earth, Marine and Environmental Sciences, edited by: Ivanovich, M., and Harman, R. S., Clarendon Press, Oxford, UK, 731-738, 1992.

Arnold, J. G., Srinivasan, R., Muttiah, R. S., and Williams, J. R.: Large Area Hydrologic Modelling and Assessment Part I: Model Development, J. Am. Water Resour. As., 34, 73-89, 1998.

Bagnold, R. A.: Bedload transport in natural rivers, Water Resour. Res., 13, 303-312, 1977.

Beniston, M.: Mountain weather and climate: a general overview and a focus on climatic change in the Alps, Hydrobiologia, 562, 3-16, 2006.

Blake, W. H., Ficken, K. J., Taylor, P., Russell, M. A., and Walling, D. E.: Tracing crop-specific sediment sources in agricultural catchments, Geomorphology, 139-140, 322-329, 2012.

Brunetti, M., Maugeri, M., Nanni, T.,Auer, I., Bohm, R., and Schoner, W.: Precipitation variability and changes in the greater Alpine region over the 1800-2003 period, J. Geophys. Res.Atmos., 111, D11107, doi:10.1029/2005JD006674, 2006.

Collins, A. L. and Walling, D. E.: Selecting fingerprint properties for discriminating potential suspended sediment sources in river basins, J. Hydrol., 261, 218-244, 2002.
Collins, A. L., Walling, D. E., and Leeks. G. J.: Source type ascription for fluvial suspended sediment based on a quantitative composite fingerprinting technique, Catena, 29, 1-27, 1997.

Collins, A. L., Walling, D. E., Stroud, R. W., Robson, M., and Peet, L. M.: Assessing damaged road verges as a suspended sediment source in the Hampshire Avon catchment, southern United Kingdom, Hydrol. Process., 24, 1106-1122, 2010.

Collins, A. L., Zhang, Y. S., Duethmann, D., Walling, D. E., and Black, K. S.: Using a novel tracing-tracking framework to source fine-grained sediment loss to watercourses at sub-catchment scale, Hydrol. Process., 27, 959-974, 2013.

Corine Land Cover (2000) Available at: http://www.eea.europa.eu/data-and-maps/data/ corine-land-cover-clc2000-100-m-version-12-2009, 2000.

Evrard, O., Navratil, O., Ayrault, S., Ahmadi, M., Némery, J., Legout, C., Lefèvre, I., Poirel, A., Bonté, P., and Esteves, M.: Combining suspended sediment monitoring and fingerprinting to determine the spatial origin of fine sediment in a mountainous river catchment, Earth Surf. Proc. Land., 36, 1072-1089, 2011.

Fuhrer, J., Beniston, M., Fischlin, A., Frei, C., Goyette, S., Jasper, K., and and Pfister, C., Climate risks and their impact on agriculture and forests in Switzerland, Clim. Change, 79, 79-102, 2006.

Flynn, K. F. and Van Liew, M. W.: Evaluation of SWAT for sediment prediction in a mountainous snowmelt-dominated catchment, $\mathrm{T}$. ASABE, 54, 113-122, 2011.

Franks, S. W. and Rowan, J. S.: Multi-parameter fingerprinting of sediment sources: uncertainty estimation and tracer selection, in: Computational Methods in Water Resources XIII, edited by: Bentley, L. R., Balkema, Rotterdam, 1067-1074, 2000.

García-Ruiz, J. M. and El Barrio, G.: Effects geomorphologiques des activités humaines dans les milleux supraforestiers des Pyrénées espagnoles, Rev. géograph. Pyrénées et du Sud-Ouest, 61, 255-270, 1990.

García-Ruiz, J. M., Puigdefábregas, J., and Creus, J.: Los Recursos Hídricos Superficiales del Alto Aragón, Instituto de Estudios Altoaragoneses, Huesca, 1985.

Garcia-Ruiz, J. M., Lasanta, T., Ruiz-Flano, P., Ortigosa, L., White, S., Gonzalez, C., and Marti, C.: Land-use changes and sustainable development in mountain areas: a case study in the Spanish Pyrenees, Landscape Ecol., 11, 267-277, 1996.

García-Ruiz, J. M., Beguería, S., López-Moreno, J. I., Lorente, A., and Seeger, M.: Los Recursos Hídricos Superficiales del Pirineo Aragonés y su Evolución Reciente, Geoforma Ediciones, Logroño, Spain, 2001.

Gellrich, M. and Zimmermann, N. E.: Investigating the regionalscale pattern of agricultural land abandonment in the Swiss Mountains: a spatial statistical modelling approach, Landscape Urban Plan., 79, 65-76, 2007.

Giannecchini, R., Naldini, G., D’Amato Avanzi, G., and Puccinelli, A.: Modelling of the initiation of rainfall-induced debris flows in the Cardoso basin (Apuan Alps, Italy), Quatern. Int., 171-172, 108-117, 2007.

Gikas, G. D., Yiannakopoulou, T., and Tsihrintzis, V. A.: Modeling of non-point source pollution in a Mediterranean drainage basin, Environ. Model Assess., 11, 219-233, 2006.

Granger, S. J., Bol, R., Butler, P. J., Haygarth, P. M., Naden, P., Old, G., Owens, P. N., and Smith, B. P. G.: Processes affecting transfer of sediment and colloids, with associated phosphorus, 
from intensively farmed grasslands: tracing sediment and organic matter, Hydrol. Process., 21, 417-422, 2007.

Heinemann, H. G.: A new sediment trap efficiency curve for small reservoirs, Water Resour. Bull., 17, 825-830, 1981.

Höchtl, F., Lehringer, S., and Konold, W.: "Wilderness" what it means when it becomes a reality - a case study from the southwestern Alps. Landscape Urban Plan., 70, 85-95, 2005.

Horton, P., Schaefli, A., Mezghani, B., Hingray, B., and Musy, A.: Assessment of climate-change impacts on alpine discharge regimes with climatemodel uncertainty, Hydrol. Process., 20, 2091-2109, 2006.

Jasper, K., Calanca, P., Gyalistras, D., and Fuhrer, J.: Differential impacts of climate change on the hydrology of two alpine river basins, Climate Res., 26, 113-129, 2004.

Koiter, A. J., Owens, P. N., Petticrew, E. L., and Lobb, D. A.: The behavioural characteristics of sediment properties and their implications for sediment fingerprinting as an approach for identifying sediment sources in river basins, Earth-Sci. Rev., 125, 24-42, 2013.

Lasanta, T., Gonzaléz-Hildalgo, J. C., Vicente-Serrano, S. M., and Sferi, E.: Using landscape ecology to evaluate an alternative management scenario in abandoned Mediterranean mountain areas, Landscape Urban Plan., 78, 110-114, 2006.

López-Moreno, J. I., Beguería, S., and García-Ruiz, J. M.: El régimen del río Ésera, Pirineo Aragonés, y su tendencia reciente, Bol. Glaciol. Aragon., 3, 131-162, 2002.

Martínez-Carreras, N., Udelhoven, T., Krein, A., Gallart, F., Iffly, J. F., Ziebel, J., Hoffmann, L., Pfister, L., and Walling, D. E.: The use of sediment colour measured by diffuse reflectance spectrometry to determine sediment sources: application to the Attert River catchment (Luxembourg), J. Hydrol., 382, 49-63, 2010a.

Martínez-Carreras, N., Krein, A., Gallart, F., Iffly, J. F., Pfister, L., Hoffmann, L., and Owens, P. N.: Assessment of different colour parameters for discriminating potential suspended sediment sources and provenance: a multi-scale study in Luxembourg, Geomorphology, 118, 118-129, 2010b.

Meusburger, K. and Alewell, C.: Impacts of anthropogenic and environmental factors on the occurrence of shallow landslides in an alpine catchment (Urseren Valley, Switzerland), Nat. Hazards Earth Syst. Sci., 8, 509-520, doi:10.5194/nhess-8-509-2008, 2008.

Motha, J. A., Wallbrink, P. J., Hairsine, P. B., and Grayson, R. B.: Determining the sources of suspended sediment in a forested catchment in southeastern Australia, Water Resour. Res., 39, 1059, doi:doi:10.1029/2001WR000794, 2003

Nash, J. E. and Sutcliffe, J. V.: River flow forecasting through conceptual models: I. A discussion of principles, J. Hydrol., 10, 282 290,1970

Navas, A. and Machín, J.: Spatial distribution of heavy metals and arsenic in soils of Aragón (northeast Spain): controlling factors and environmental implications, Appl. Geochem., 17, 961-973, 2002.

Navas, A., Soto, J., and López-Martínez, J.: Radionuclides in soils of Byers Peninsula, South Shetland Islands, Western Antarctica, Appl. Radiat. Isotopes, 62, 809-816, 2005a.

Navas, A., Soto, J., and Machín, J.: Mobility of natural radionuclides and selected major and trace elements along a soil toposequence in the central Spanish Pyrenees, Soil Sci., 170, 743-757, $2005 b$.
Navas, A., López-Vicente, M., Gaspar, L., Palazón, L., and Quijano, L.: Establishing a tracer based sediment budget to preserve wetlands in Mediterranean mountain agroecosystems (NE Spain), Sci. Total Environ., 496, 132-143, 2014.

Neitsch, S. L., Arnold, J. G., Kiniry, J. R., Srinivasan, R., and Williams, J. R.: Soil and Water Assessment Tool Input/output fifi le documentation: Version 2009, USDA, Soil and Water Research/Blackland Research Center, Texas, 2010.

Owens, P. N., Walling, D. E., and Leeks, G. J. L.: Tracing fluvial suspended sediment sources in the catchment of the River Tweed, Scotland, using composite fingerprints and a numerical mixing model, in: Tracers in Geomorphology, edited by: Foster, I. D. L., John Wiley and Sons Ltd., Chichester, 291-308, 2000.

Palazón, L. and Navas, A.: Sediment production of an alpine catchment with SWAT, Z. Geomorphol., 57, 69-85, 2013.

Palazón, L., and Navas, A.: Modeling sediment sources and yields in a Pyrenean catchment draining to a large reservoir (Ésera River, Ebro Basin), J. Soil Sediment., 14, 1612-1625, doi:10.1007/s11368-014-0911-7, 2014.

Puigdefábregas, J. and Creus, J.: Pautas espaciales de la variación climática en el Alto Aragón., Publ. Centro Pirenaico de Biol. Exp., 7, 23-34, 1973.

Rahman, K., Maringanti, C., Beniston, M., Widmer, F., Abbaspour, K., and Lehman, A.: Streamflow modeling in a highly managed mountainous glacier watershed using SWAT: the Upper Rhone River watershed case in Switzerland, Water Resour. Manage., 27, 323-339, 2013.

Rostamian, R., Jaleh, A., Afyuni, M., Mousavi, S. F., Heidarpour, M., Jalalian, A., and Abbaspour, K. C.: Application of a SWAT model for estimating runoff and sediment in two mountainous basins in central Iran, Hydrolog. Sci. J., 53, 977-988, 2008.

Schindler Wildhaber, Y., Bänninger, D., Burri, K., and Alewell, C.: Evaluation and application of a portable rainfall simulator on subalpine grassland, Catena, 91, 56-62, 2012.

Schmidli, J. and Frei, C.: Trends of heavy precipitation and wet and dry spells in Switzerland during the 20 century, Int. J. Climatol., 25, 753-771, 2005.

Schuller, P., Walling, D. E., Iroumé, A., Quilodrán, C., Castillo, A., and Navas, A.: Using ${ }^{137} \mathrm{Cs}$ and ${ }^{210} \mathrm{~Pb}_{\text {ex }}$ and other sediment source fingerprints to document suspended sediment sources in small forested catchments in south-central Chile, J. Environ. Rad., 124, 147-159, 2013.

Smith, H. G. and Blake, W. H.: Sediment fingerprinting in agricultural catchments: A critical re-examination of source discrimination and data corrections, Geomorphology, 204, 177-191, 2014.

Smith, H. G., Sheridan, G. J., Lane, P. N. J., Noske, P. J., and Heijnis, H.: Changes to sediment sources following wildfire in a forested upland catchment, southeastern Australia, Hydrol. Process., 25, 2878-2889, 2011.

Stanchi, S., Freppaz, M., Godone, D., and Zanini, E.: Assessing the susceptibility of alpine soils to erosion using soil physical and site indicators, Soil Use Manage., 29, 586-596, 2013.

Valero-Garcés, B., González-Sampéíriz, P., Navas, A., Machín, J. Mata, P., Delgado-Huertas, A., Bao, R., Moreno Caballud, A., Carrión, J., Schwalb, A., and González-Barrios, A.: Human impact since medieval times and recent ecological restoration in a Mediterranean Lake: The Laguna Zoñar, southern Spain, J. Paleolimnol., 35, 441-465, 2006. 
Van Cleef, D. J.: Determination of ${ }^{226} \mathrm{Ra}$ in soil using ${ }^{214} \mathrm{~Pb}$ and ${ }^{214} \mathrm{Bi}$ inmediately after sampling, Health Phys., 67, 288-289, 1994.

Walden, J., Slattery, M. C., and Burt, T. P.: Use of mineral magnetic measurements to fingerprint suspended sediment sources: approaches and techniques for data analysis, J. Hydrol., 202, 353-372, 1997.

Walling, D. E.: The evolution of sediment source fingerprinting investigations in fluvial systems, J. Soil Sediment, 13, 1658-1675, 2013.

Wilkinson, S. N., Hancock, G. J., Bartley, R., Hawdon, A. A., and Keen, R. J.: Using sediment tracing to assess processes and spatial patterns of erosion in grazed rangelands, Burdekin River basin, Australia, Agr. Ecosyst. Environ., 180, 90-102, 2012.

Williams, J. R.: Sediment-yield prediction with universal equation using runoff energy factor, in: Present and prospective technology for predicting sediment yield and sources, in: Proceedings of the Sediment-Yield Workshop, USDA sediment Lab, Oxford, 244-252, 1975.
Williams, J. R. and Berndt, H. D.: Sediment yield prediction based on watershed hydrology, Transact. Amer. Soc. Agricult. Biol. Engin., 20, 1100-1104, 1977.

Yu, M., Chen, X., Li, L., Bao, A., and de la Paix, M. J.: Streamflow simulation by SWAT using different precipitation sources in large arid basins with scarce raingages, Water Resour. Manag., 25, 2669-2681, 2011.

Yu, L. and Oldfield, F.: A multivariate mixing model for identifying sediment source from magnetic measurements, Quaternary Res., 32, 168-181, 1989.

Zhang, X., Srinivasan, R., Debele, B., and Hao, F.: Runoff simulation of the headwaters of the Yellow River using the SWAT model with three snowmelt algorithms, J. Am. Water Resour. As., 44, 48-61, 2008. 